\title{
Articles
}

\section{FINANCIAL DISTRESS AND ACCESS TO CAPITAL IN EMERGING MARKETS}

\author{
Jorge Guillen*
}

\begin{abstract}
:
In this paper I study the main determinants of successful reaccess to international capital markets on a set of emerging market countries after a financial crisis. I focus on three components of the reaccess strategy: commitment to pay, ability to pay, and global liquidity. I employ a panel of 49 countries over a nearly 30-year period and apply a simple probit approach to show that, indeed, a sound external position and a sustainable debt profile, accompanied by a favorable global liquidity environment, are the key considerations for creditors considering whether to resume lending.
\end{abstract}

Keywords: sovereign debt, reaccess, international finance, developing countries.

JEL Classification: F34, G15, O10

\section{Introduction}

In this paper I analyze the recent episodes of the development in the countries that have emerged from a severe financial crisis, including debt restructuring, and I investigate emprically the main determinants of their successful reaccess to international capital markets. This study conjectures that a sovereign, after emerging from a financial crisis, uses a set of internal and external indicators to signal its renewed creditworthiness and its intention and capacity to meet its obligations. On the domestic side, a sound macroeconomic stance, as reflected by low rates of inflation or sensible budget balances, may be indicating to creditors a strong commitment to repay. On the external side, an

* University ESAN, Lima; Alonso de Molina 1652, Monterrico, Surco (jguillen@esan.edu.pe). I am grateful to Vanessa Rios and Paola Vargas for many comments and suggestions. The usual disclaimer applies. 
adequate level of international reserves and of the current account balance may signal to creditors the sovereigns' ability-to-repay new debt. Furthermore, international investors, prior to resume lending, will not only evaluate the sovereign commitment and ability to repay but also seek satisfactory returns from their investment. While indicators for economic activity in the country may be assumed as providing potential investors with some indication of potential price appreciation of new bond issuances, creditors will evaluate the returns from resuming lending to a country in the context of the global liquidity cycle. In particular, global liquidity in international capital markets, as proxied by the level of interest rates in mature market countries, may impact the expected returns from new lending.

There are two complementary views regarding the ability of countries to reaccess international financial markets after a financial crisis. On the one hand, the literature on external debt has shown that governments have an incentive to meet their obligations and to preserve their reputation as creditworthy borrowers because uninterrupted financing flows imply a higher level of consumption or because repayment is enforced by a credible threat by creditors of possible economic and political sanctions (Bulow, Rogoff, 1988, 1989). In either case, creditors are willing to lend because they are confident that repayment will occur (Eaton, Gersovitz, 1981). A default then signals that the sovereign is either no longer willing to service its obligations or that the creditors' threat is no longer credible. Thus, a default would be expected to cause a permanent interruption of the financing flows as international creditors will be reluctant to resume lending to debtor countries that have been unreliable in servicing their debt, while a sovereign that defaults is expected to find serious difficulties in obtaining new financing (Bulow, Rogoff, 1988, 1989; Atkenson, 1991).

On the other hand, it has been maintained that despite the event of a default, a sovereign will be able to borrow again if creditors differentiate between excusable defaults and debt repudiation or if the country engages in significant efforts to rebuild its reputation as a creditworthy borrower. In some cases, the nature of the crisis which led a sovereign to default may be important to explain why creditors' financing resumed as creditors would be able to differentiate between excusable defaults, associated with implicitly understood contingencies and unjustifiable repudiation (Grossman, van Huyck, 1988). In particular, the sovereign's reputation as a trustworthy borrower may remain untarnished after an excusable default, but would be lost in all other cases. If the cause of the default is exogenous, the financial flows to sovereigns may continue despite episodes of default. This has led many to conclude that, the debtors' reputation is the main determinant of lending (Cole, Dow, English, 1995). According to this view, a sovereign will be able to reaccess international capital markets provided it shows renewed commitment to service its obligations and financial means to support it. The specific mechanism to rebuild trustworthiness may be through the adoption a comprehensive set of sound economic policies, for example, austerity programs, which signal both political stability and a solid financial position. ${ }^{1}$

The existing empirical evidence shows that sovereigns tend to repay their debt as

1 Related studies by Diamond (1989), Atkeson (1991), and, more recently, Sole (2004), suggest that the reputation of a sovereign borrower is also closely linked to the return on the projects it is undertaking with the loaned funds. In particular, they note that lenders will be willing to resume lending provided the return from the project remains positive in their projection period. 
such debt typically yields positive ex-post returns (Eichengreen, Portes, 1986; Lindert, Morton, 1990; Klingen, Zettelmeyer, Weder, 2004). However, it is not clear what determines lending to resume in countries that suffered financial crises and structural institutional weakness as there does not exist evidence on this issue. For instance, Gelos et al. (2004) and Grigorian (2003) investigate the circumstances under which a country gains access to international capital markets but barely focus on the specific case of sovereigns seeking new financing after experiencing difficulties in servicing their debt. From a policy perspective, the issue of reaccess bears the utmost importance as most developing countries in Latin America, and several in Asia and Africa have to deal with reaccess after crises rather than simply access issues. In the context above, the aim of this paper is to focus specifically on the issue of market reaccess after countries have undergone financial and debt crisis.

The paper is organized as follows. Section 2 decribes the empirical methodology; Section 3 describes the data; Section 4 shows my findings using different econometric methodologies and dependent variables definitions. Section 5 summarizes and concludes.

\section{Empirical Methodology}

The variable of interest is the event of reaccessing the markets which, in its more general case, may be defined as a categorical event from the perspective of an investor. For instance, a country may be given full access to international capital markets by selling a new bond, or no access at all. I focus on the case where the dependent variable is dichotomous for several reasons. In the first place, the aim of this study is to analyze the determinants of the event of reaccessing the markets: a continuous variable representing such event, such as, for example, the volume of the reaccess issues, would also depend on other considerations than those that allow just for the event of reaccess, including, in this example, the financing needs. In the second place, it would be difficult to identify an ordinal dependent variable by identifying different categories of reaccess, as those generated, for example, by categories of partial access levels. Finally, interpretation of results is typically much more straightforward when using simple probits rather than ordered probits as, in the latter case, marginal effects are produced for each reaccess category. In this case, a simple probit technique allows to take into consideration the binary nature of the dependent variable in this research, namely whether a country has access or not to international markets. For instance, in the case of 2 degrees of reaccess categories, the dependent variable takes value 0 if the country has not reaccessed the market and 1 when the country reaccesses the market, then the empirical model follows the following specification:

$$
\begin{gathered}
\operatorname{Pr} o b(Y i=0)=\phi\left(\beta^{\prime} X\right) \\
\operatorname{Pr} o b(Y i=0)=1-\phi\left(\beta^{\prime} X\right)
\end{gathered}
$$

where $\mathrm{Y}_{\mathrm{i}}$ is a random variable indicating whether a country reaccesses markets after a crisis - which takes a value of 0 if there is no new issue and value 1 when a new bond is sold in the market following the crisis; $\mathrm{X}$ is a vector of domestic (commitment 
to pay), international (ability to pay), and global characteristics (interest rates) and the function $\Phi($.$) is the standard normal distribution. The log-likelihood can be derived for$ the 2 possible outcomes, in particular:

$$
\ln L=\sum_{i=1}^{n}\left\{y_{i} \ln \Phi\left(\beta^{\prime} x\right)+\left(1-y_{i}\right) \ln \left[1-\Phi\left(\beta^{\prime} x\right)\right]\right\}
$$

Once the likelihood is formed, the estimation of the unknown parameters $\beta^{1}$ can be undertaken by maximizing the log-likelihood function (2). The impact of a change in an explanatory variable on the estimated probabilities of the lowest and the highest of the ordered classification is direct. For instance, if $\beta_{\mathrm{k}}$ is positive, an increase in increases the probability of reaccess category and decreases the probability of not reaccessing. However, the impact on estimated probabilities of intermediate categories is not direct. Note that an estimated value does not estimate the change in probability of a given outcome. By manipulation of (1) it can be shown that the marginal effects of the attributes on the corresponding probabilities are:

$$
\frac{\partial E\left(y_{i} / x_{k}\right)}{\partial x_{k}}=+\phi\left(\beta^{\prime} X\right) \beta_{k}
$$

While the data set is comprised of panel data, a random effects estimator was not considered as the best estimator because, in this case, the assumption that individual effects were uncorrelated with explanatory variables is too restrictive, as certain macroeconomic variables do depend on country specific characteristics, such as the institutional framework. The case for applying fixed effects in probit estimations is even more complex as they are subject to severe biases due to the incidental parameters, problem as noted in Hsiao $(1993,1996)$ and Green $(2004){ }^{2}$ However, the inclusion of global liquidity indicators among the explanatory variables, as represented by the interest rate for the US treasury bills, does allow to control for business cycle-type of effects (time effects) across the estimates.

All regressions were corrected for heteroskedasticity in errors. To avoid high correlation between some of the indicators of macroeconomic policies and the country's own growth rate, the growth rates were included in lagged form. ${ }^{3}$ To perform sensitivity analysis of the estimates to specific variable selection, different indicators were used to proxy for external and domestic macroeconomic soundness and were introduced alternatively in the regressions.

While theoretically endogeneity may be a problem, the size of a bond issue is typically too small with respect to the macroeconomic magnitudes of the typical regressors in the equation to be estimated. It seems unreasonably difficult that a new bond would affect the size of the current account balance or the rate of inflation. However, to check for this possibility, the probit parameters were also estimated using an instrumental variables approach with lagged values as instruments. In all

2 Even in the case the chosen methodology would have been logit estimations, it would not have been possible to apply fixed country effects to the estimations because the method to remove group heterogeneity would have implied excluding from the sample all the countries that having experienced a crisis did not reaccess international capital markets during the period under consideration (Green, 1997).

3 Findings do not change if lags are not included. 
regressions, the significance and direction of the estimated coefficients was unchanged by the use of instruments, thus suggesting that the biases due to endogeneity in the probit estimates were limited. ${ }^{4}$

Finally, a number of regressions were run by including interactive terms to control for the way the sovereign had managed the financial crisis, either through a debt reduction or through negotiating exceptional liquidity support - and thus committing upfront to sound macroeconomic policies while averting losses to the creditors, implied a significant difference in the size and/or significance of the impact of specific variables on the probability of reaccess. For this purpose, two dummy variables were constructed, one identifying the episodes of crisis were the sovereign restructured or defaulted on bonds or loans, the other to identify episodes where exceptional liquidity support was granted by the IMF and the debt restructuring was averted. The interactive variables were constructed by multiplying each dummy with the different macroeconomic variables signaling creditworthiness. The advantage of this approach is, that it allows to identify whether the coefficients impacting the probability of reaccess depend also on whether the creditors suffered a financial loss from the crisis or not.

\section{Data}

It may be possible to conjecture that a sovereign, that has undergone a financial crisis, will be able to reaccess the markets if it successfully signalled commitment and ability to repay its debt and investors value favorably the returns from resuming lending in the context of the global liquidity cycle. As mentioned above, macroeconomic indicators of such conditions will then constitute the explanatory variables of the equation modelling the probability that a sovereign reaccesses the markets. In particular, a sovereign's commitment of a country to repay foreign currency debt may be proxied by domestic policy indicators, including the domestic rate of inflation, the fiscal balance, the total stock of outstanding debt, and a political conditions index. Low inflation, debt ratios and fiscal deficit imply sound domestic macroeconomic management. The inclusion of an institutional index summarizes good governance practices in the country.

Similarly, a sovereign's ability to repay foreign currency debt may be proxied by external policy variables, such as the total amount of reserves as a share of short term debt, total debt service as a share of reserves, the level of reserves in terms of months of imports, as well as the external current account balance. High levels of reserves and low current account deficits would indicate a country's strong external position good foreign receipts. The presence of an International Monetary Fund (IMF) program may be considered as a signal for a country's ability to repay as it provides liquidity support. Investors expected returns from resuming lending may be proxied by an indicator of economic activity, GDP growth rates, which were assumed to represent the real return from investment in the country.

Finally, global liquidity conditions were proxied by interest rates prevailing in the United States Treasury bills. The higher global liquidity, the lower the interest rates

$4 \quad$ These results are not presented but are available upon request. 
prevailing in the United States, the more likely investors would be to lend to emerging market countries. ${ }^{5}$

However, it is important to note that both GDP growth rates and the fiscal deficit could also reflect in a sovereign's strong domestic demand for foreign financing. This would imply that their inclusion in the regressions was controlling for the sovereigns' demand for new financing. Ultimately, the sign of the estimated coefficient was expected to indicate whether a demand or a "good policy" signal effect was more important in determining the event of reaccess than the financing needs.

It is important to note that, in order to minimize issues of cross-correlation and joint endogeneity across explanatory variables, only one indicator for each condition for reaccess was included in the estimations at a time. ${ }^{6}$ In addition, lagged GDP growth rates were included rather than contemporaneous ones, as they tend to be associated with many macroeconomic indicators. Alternative specifications of the same indicator, as discussed above, were used to perform sensitivity analysis. In this way, the different proxies for the ability to pay, the current account balance, the debt ratio, and the different reserve ratios were introduced alternatively in the baseline equation. This allowed both to evaluate which signal of ability to pay was the most significant in affecting the likelihood a country reaccessed the markets and at the same time to analyze the sensitivity of the estimates for coefficients on the other explanatory variable. The same system was applied for indicators of the commitment to repay.

The dataset comprises of 49 emerging market countries that have been active issuers in the international capital markets with annual data over the period 1980-2007. ${ }^{7}$ Data on financial crises have been compiled and divulged by Standard and Poor's (S\&P) in regular publications and comprise of a set of episodes in which sovereigns either defaulted or restructured their external obligations, which resulted in a loss to the creditors. ${ }^{8}$ A default is defined as an episode where an obligor fails to meet a principal or interest payment on the due date, or within the specified grace period, contained in the original terms of the debt issue. In particular, (i) in the case of local and foreign currency bonds, notes, and bills, each issuer's debt is considered in default either when scheduled debt service is not made on the due date or when an exchange offer of new debt contains less favorable terms than the original issue; and (ii) in the case of bank loans, when either scheduled debt service is not made on the due date or a rescheduling of principal and/or interest is agreed to by creditors at less favorable terms than the original loan. Such rescheduling agreements covering short- and long-term bank debt are considered a default even where, for legal, or regulatory reasons, creditors deem forced rollover or principal to be voluntary (Chambers, Alexeeva, 2002).

5 A number of regressions were also run with alternative macroeconomic indicators than the ones mentioned above, in particular, monetary conditions indices for commitment to repay, exports to total debt as indicator of ability to repay, GDP growth of the US and a volatility in bond markets index as indicators of global cyclical conditions, but were not found to be significant.

6 Principal components estimation was also performed and estimations are available upon request, however, this methodology does not allow for any meaningful interpretation of the coefficient and is criticized and discouraged by Green (1997).

7 Appendix 1 lists the countries included in this research.

8 Global bonds have become popular only since the early nineties and earlier forms of external financing for emerging market countries mainly took the form of syndicated loans. 
While in the episodes compiled by S\&P a financial crisis was managed through a debt reduction, by defaulting or by renegotiating its obligations, in other circumstances, multilateral lending providing exceptional liquidity support may help the sovereign to remain current on its bilateral obligations while facing a financial crisis. In this respect, Manasse, Roubini and Schimmelpfennig (2003) have identified episodes of financial crisis in which sovereigns were granted access to exceptional liquidity support by multilateral financial institutions. In particular, the sovereigns were allowed access to IMF financing for over 100 percent of their quota, but were not considered a "default" according to S\&P.

It is important to note that in those cases where the financial crisis was managed through negotiating exceptional liquidity support, differently from those compiled by S\&P, private creditors did not undergo any loss from lending to the sovereign, although, in both cases, the financial crisis entailed a loss of market access to the sovereign. As an additional observation, countries had to commit upfront to sound macroeconomic policies in order to qualify for a disbursement under the exceptional financing facility, thus providing "ipso facto" a signal for strong commitment-to-repay their external debt.

Within the period 1980 to 2007 and using both datasets discussed above, I am able to compile 51 episodes of financial crisis across a set of 39 different countries; in 42 cases there was restructuring of sovereign debt and in 9 cases a country was granted exceptional liquidity support via access to the International Monetary Fund's financing. Both episodes of loan and bond restructuring were included in the sample because the greater part of sovereign lending in 1980-90 took the form of syndicated loans.

The event of "reaccessing the markets" was defined by the placing of a new sovereign bond in the international capital markets for the first time after a financial crisis. ${ }^{9}$ Given the set of 51 financial crises across the 39 countries of the sample, an event of reaccess was identified by a successful issue of a new bond in the time period following the crisis. My data comprises 37 episodes of reaccess to the market by 27 different sovereigns. ${ }^{10}$ It is important to note that any issuance of bonds in exchange for existing bonds following a restructuring agreement between a sovereign and its creditors in the context of a resolution of a financial crisis was not considered as an episode of reaccess. The so-called Brady bonds, issued after the large debt crisis in Latin America at the end of the 1980s, is an example of this. ${ }^{11}$

9 There are cases in which the first issue by a sovereign after a crisis was made in the domestic capital market but such episodes are excluded for purposes of this analysis as they deviate from the focus of my research.

10 All episodes where new financing was achieved through a loan syndication were excluded from the sample as this form of financing involves only very few lenders. In addition, loan financing has become a secondary form of financing emerging markets sovereigns during the last decade. This definition differs from that used in Gelos et al. (2004) that uses events of both new bond issuance and new loan syndication to define "market access".

11 Notwithstanding this statistics, the number of episodes where countries had to restructure their bonds remains limited to date, mostly reflecting the fact that events of restructuring are still quite rare in international financial markets. 
The data on bond issuances comes from Bondware Dealogic. This private firm registers single bond issues in the international markets, including most of the characteristics of each issue, such as amounts, terms, conditions, syndicates, issuers characteristics, and so forth. ${ }^{12}$ I compile the relevant bond issues by governments for the period of relevance, 1980-2007 at the country level. Additionally, institutional data were obtained from the well-known International Country Risk Guide dataset (ICRG, 2006). These data were originally used by Knack and Keefer (1995), Hall and Jones (1999), and several other researchers. The ICRG risk rating system assigns a numerical value to a predetermined range of risk components for about 130 countries. In this paper I use the five most commonly used institutional dimensions used in the literature: (i) government stability, (ii) corruption, (iii) law and order, (iv) democratic accountability, and (v) bureaucracy quality. As in Knack and Keefer (1995) I computed an average of these five dimensions annually for the 1980-2003 period. Additionally, the macroeconomic indicators were taken from the International Monetary Fund (2006) and from the World Bank (2006). Finally, data on IMF programs is available on the website of the International Monetary Fund. ${ }^{13}$

\section{Findings}

Table 1 in the Appendix shows the countries and episodes of crisis and reaccess for the countries employed in this paper. Table 2 shows basic summary statistics of all the variables utilized in my research.

Table 3 presents the marginal effects and corresponding statistically significance of the multivariate simple probit estimates for all countries that underwent a financial crisis. The first column presents the chosen baseline regression, as it presents the best fit. In this specification, the probability that a country would reaccess the markets will be affected by the global liquidity cycle, total debt to GDP to indicate the domestic policy stance, the level of the current account to signal the external position and the lagged GDP rate indicating the return from investment in the country. The following columns conduct sensitivity analysis with respect to the baseline specification and, at the same time, control whether a sovereign could be using different indicators to signal either commitment or ability to repay, and thus whether such variables are also significant in determining reaccess to markets. In particular, columns 2 to 5 in the same table include different indicators of the domestic policy stance other than the total stock of total debt to GDP, to signal commitment-to-repay, while columns 6 to 10 include alternative indicators of the external position, in particular indicators of reserve levels, to signal a sovereign's the ability to repay its foreign debt.

The elements that appeared to impact most significantly the probability that a sovereign would reaccess markets are its perceived ability to repay as signalled by the current account deficit, and the global liquidity cycle, as proxied by the level of US interest rates which affects creditors' evaluation of the returns from the new investment.

12 The quality of the information provided by this firm is confirmed by the fact that it sells this product at a high price and after a number of years the demand for its product in both the private and public sectors is still very strong.

$13 \mathrm{http}: / /$ www.imf.org 
In particular, according to the marginal impact on the probability, a one percentage point increase in the yields of US treasury interest rates reduces the probability of reaccessing the markets by, on average, 13 percent. In the case indicators of ability to repay, a one percent improvement in the current account deficit was found to increase the probability of reaccess by, on average, 20 percent. A sovereign's commitment to repay, as signalled indicators of sound domestic policies: debt levels, inflation levels and domestic political conditions, appeared also be a significant determinant of reaccess. However, the size of their impact appeared to be limited. Finally, investors' expected returns from the new lending, as proxied by lagged GDP growth rates, also appeared to impact the probability of reaccess, although the estimates were not very robust. We also tested estimations when some of the explanatory variables of the general regression are interacted with dummies variables which define the type of financial crisis the countries underwent prior to reaccess. Overall the regressions with interacted variables highlight how indicators of commitment to repay, such as the total debt level to GDP appear to bear a significant impact on the probability of reaccess in those cases where debt was restructured and creditors suffered losses. However, debt sustainability indicators tend not to be significant in those cases access to liquidity support was granted. In such cases, indicators of the ability to pay, such as the current account deficit and the level of debt service to reserves appear to have a stronger impact on the probability of reaccessing the market than for the rest of the sample. ${ }^{14}$

Table 4 presents the estimates when instrumental variables are employed in order to control for possible endogeneity in our specification. The instruments we employ are the lagged values of the explanatory variables considered potentially endogenous as well as the legal origin of the corresponding country under consideration. The most noticeable outcome is that in all regressions the significance and the direction of the estimated coefficients are unchanged by the use of instruments thereby suggesting that possible biases due to endogeneity may not be of great concern. Additionally, the tables report corresponding Wald text on the excluded variables that confirm the appropriateness of the instruments employed..$^{15}$

\section{Summary and Conclusions}

This paper conjectures that a sovereign that is emerging from a financial crisis signals its intention to become a creditworthy borrower by undertaking sound domestic macroeconomic policies (i.e., commitment to repay) and signals its ability to repay foreign debt through indicators of external soundness (i.e., ability to repay). In addition, foreign investors evaluate whether to resume lending on the basis of the expected rate of return of their investment subject to the global liquidity cycle. The empirical investigation sought to analyze which set of macroeconomic indicators increases the likelihood that a sovereign emerging from a crisis will reaccess international capital markets.

14 Given the nature of our results we do not provide detailed findings of the interactions but they are available upon request.

15 Specifications using interactive terms were also tested. Such terms give no significant statistical coefficients. These results are available upon request. 
Estimation results provide support to the conjecture that signals of both ability and commitment to repay external obligations are statistically significant when a sovereign seeks to reaccess market, although indicators of external soundness appear to have a relatively larger impact and, also, appear particularly effective in the case of countries that, despite suffering a crisis, were able to avoid restructuring their debt. Results also show that international investor demand is fundamental when countries seek reaccess to markets as the global liquidity cycle appears to be a factor that significantly affects the likelihood of reaccessing. In general, indicators of a sound macroeconomic stance, including the presence of an IMF program, a signal of a country's commitment to sound macroeconomic policies, is also found to be statistically significant in determining reaccess.

Results also evidence how lenders, when considering whether to resume new lending, differentiate between countries that underwent a debt restructuring or defaulted and countries that were able to avert a default by negotiating exceptional liquidity support. In particular, total debt ratios were found to be significant in increasing the likelihood of reaccess only for sovereigns which underwent a restructuring of their obligations. This suggests that, in such cases, creditors take into considerations long-term debt-sustainability indicators when evaluating whether to resume lending. In contrast, the size of the impact of external soundness indicators was found to be largest in increasing the likelihood of reaccess of countries that did not restructure their obligations, which suggest that creditors, in such cases, focus on short-term indicators of the ability-to-repay, which tend to be more of a short term nature.

To conclude, estimation results support the theoretical prediction that, overall, sound external and domestic policies together with a favorable global liquidity environment are key considerations for creditors considering whether to resume lending to sovereigns that suffered financial crises.

\section{References}

Anderson, T. W., Hsiao, C. (1993), The Econometrics of Panel Data. Vol. 1. Elgar Reference Collection Series. International Library of Critical Writings in Econometrics. Aldershot, U.K.: Elgar; distributed in the U.S. by Ashgate, Brookfield, Vt.

Atkenson, A. (1991), "International Lending with Moral Hazard and Risk of Repudiation" Econometrical, Vol. 59, No. 4 (July), pp: 1069-89.

Bulow, J., Rogoff, K. (1989a), "A Constant Reconstructing Model of Sovereign Debt” Journal of Political Economy Vol. 97, No. 1 (February), pp: 155-78.

Bulow, J., Rogoff, K. (1989b), "Sovereign Debt Is to Forgive or to Forget?" American Economic Review. Vol. 79, No. 1 (March), pp: 43-50.

Chambers, J., Alekseeva, D. (2002), "Rating Performance 2002, Default, Transition, Recovery, and Spreads," Standard and Poor's.

Cole, H. L., Dow, J., English, W. B. (1995), "Default, Settlement, and Signalling: Lending Resumption in a Reputational Model of Sovereign Debt", International Economic Review, Vol. 36, No. 2, pp: 365-385.

Diamond, D. W. (1989), "Reputation Acquisition in Debt Markets” Journal of Political Economy, Vol. 97 No. 4 (November), pp: 828-862.

Eaton, J., Gersovitz, M. (1981), "Debt with Potential Repudiation: Theoretical and Empirical Analysis" Review of Economic Studies, Vol.48, No.2 (April), pp: 289-309. 
Eaton, J., Fernandez, R. (1995), "Sovereign Debt" in Handbook of International Economics. Vol. 3, pp: 2031-77; Handbooks in Economics, Vol. 3. Amsterdam; New York and Oxford: Elsevier, NorthHolland, 1995.

Eichengreen, B., Portes, R. (1986), "Debt and Default in the 1930s: Causes and Consequences", NBER Working Paper 1772.

Gelos, G. R., Sahay, R., Sandleris, G. (2004), "Sovereign Borrowing by Developing Countries: What Determines Market Access?" IMF Working Paper No. 04/221, (Washington: International Monetary Fund).

Green, W. (1997), Econometric Analysis. Prentice-Hall International Limited, London.

Green, W. (2004), "Convenient Estimators for the Panel Probit Model: Further Results" Empirical Economics, Vol. 29, pp: 21-47.

Grigorian, D. (2003), "On The Determinants of First-Time Sovereign Bond Issues" IMF Working Paper No. 03/184, (Washington: International Monetary Fund).

Grossman, H. I., Van Huyck. J. B. (1988), "Sovereign Debt as a Contingent Claim: Excusable Default, Repudiation and Reputation", American Economic Review, Vol.78, No. 5 pp: 1088-1097.

Hall, R. E., Jones. C. I. (1999), "Why Do Some Countries Produce So Much More Output per Worker than Others?' Quarterly Journal of Economics, Vol. 114, No. 1 pp: 83-116.

Hsiao, C. (1996), The Econometrics of Panel Data: A Handbook of the Theory with Applications. Second edition. Advanced Studies in Theoretical and Applied Econometrics, Vol. 33. Dordrecht; Boston and London: Kluwer Academic.

International Country Risk Guide (2006),http://www.ircig.org

International Monetary Fund (2006), World Economic Outlook, Washington, DC.

International Monetary Fund (2005), "Assessing the Determinants and Prospects for the Pace of Market Access by Countries Emerging from Crises - Further Considerations," SM/05/76, (5/16/05).

International Monetary Fund (2001), "Assessing the Determinants and Prospects for the Pace of Market Access by Countries Emerging from Crises - Country Cases," EBS/01/157, (9/6/01).

Klingen, C., Weder, B., Zettelmeyer, J. (2004), "How Private Investors Fared in Emerging Debt Markets, 1970-2000". IMF Working Paper No. 04/13, (Washington: International Monetary Fund).

Knack, S., Keefer, P. (1995), "Institutions and Economic Performance: Cross Country Tests Using Alternative Institutional Measures". Economics and Politics, Vol. 7, No. 3, pp: 207-27.

Lindert, P. H., Morton, P. J. (1990), "How Sovereign Debt Has Worked", in Sachs, J. (ed.) Developing Country Debt and Economic Performance, Vol. 1, 39-105. Chicago: University of Chicago Press.

Manasse, P., Roubini, N., Schimmelpfennig, A. (2003), "Predicting Sovereign Debt Crises," IMF Working Paper No. 03/221, (Washington: International Monetary Fund).

Sole, J. (2004), "Lending Resumption after Default: Lessons from the Capital Markets During the 19th Century" IMF Working Paper No. 06/176, (Washington: International Monetary Fund).

Standard \& Poor (1997), "Behind the Ratings. Sovereign Credit Ratings: A Primer," Standard \& Poor's Credit Week, (April 16), pp. 21-28.

Standard \& Poor (2005), "Sovereign Defaults: Heading Lower Into 2006", 18 September 2005.

World Bank (2006), World Development Indicators, CD ROM, Washington, DC. 


\section{Appendix 1}

\section{List of Countries in Dataset}

\begin{tabular}{|c|c|c|c|}
\hline 1 & Argentina & 26 & Mauritius \\
\hline 2 & Brazil & 27 & Mexico \\
\hline 3 & Bulgaria & 28 & Moldova \\
\hline 4 & Chile & 29 & Morocco \\
\hline 5 & Colombia & 30 & Oman \\
\hline 6 & Costa Rica & 31 & Pakistan \\
\hline 7 & Croatia & 32 & Panama \\
\hline 8 & Cyprus & 33 & Papua \\
\hline 9 & Dominican Republic & 34 & New Guinea \\
\hline 10 & Ecuador & 35 & Peru \\
\hline 11 & Egypt & 36 & Philippines \\
\hline 12 & El Salvador & 37 & Poland \\
\hline 13 & Estonia & 38 & Qatar \\
\hline 14 & Grenada & 39 & Romania \\
\hline 15 & Guatemala & 40 & Russia \\
\hline 16 & Hungary & 41 & Saudi Arabia \\
\hline 17 & Indonesia & 42 & Slovak Republic \\
\hline 18 & Israel & 43 & Slovenia \\
\hline 19 & Jamaica & 44 & South Africa \\
\hline 20 & Kazakhstan & 45 & Sri Lanka \\
\hline 21 & Korea & 46 & Thailand \\
\hline 22 & Latvia & 47 & Turkey \\
\hline 23 & Lebanon & 48 & Ukraine \\
\hline 24 & Lithuania & 49 & Uruguay \\
\hline 25 & Malaysia & 50 & Venezuela, Rep. Bol. \\
\hline
\end{tabular}


Table 1

Countries and Episodes of Crisis and Reaccess in the Full Sample 1980-2007 1/2/3/

\begin{tabular}{|c|c|c|c|}
\hline \multicolumn{2}{|c|}{ List of Crisis Episodes } & \multicolumn{2}{|c|}{ List of Reaccess 1980-2007 } \\
\hline Country & Year & Country & Year \\
\hline Argentina & 1982 & --- & --- \\
\hline Argentina & 1989 & Argentina & 1991 \\
\hline Argentina & $1995 * 4 /$ & Argentina & 1996 \\
\hline Argentina & 2001 & --- & --- \\
\hline Brazil & 1983 & Brazil & 1995 \\
\hline Brazil & 1998 * & Brazil & 1999 \\
\hline Brazil & 2002 * & Brazil & 2002 \\
\hline Chile & $19835 /$ & Chile & 1999 \\
\hline Costa Rica & 1981 & --- & --- \\
\hline Costa Rica & 1984 & Costa Rica & 1998 \\
\hline Croatia & $19925 /$ & Croatia & 1996 \\
\hline Dominican Republic & 1982 & --- & --- \\
\hline Dominican Republic & 1999 & Dominican Republic & 2001 \\
\hline Ecuador & $19825 /$ & Ecuador & 1997 \\
\hline Ecuador & 1999 & --- & --- \\
\hline Egypt & $19845 /$ & Egypt & 2001 \\
\hline Guatemala & $19865 /$ & --- & --- \\
\hline Guatemala & 1989 & Guatemala & 1997 \\
\hline Indonesia & 1998 & --- & --- \\
\hline Indonesia & $20025 /$ & Indonesia & 2003 \\
\hline Jamaica & $19815 /$ & --- & --- \\
\hline Jamaica & $19885 /$ & Jamaica & 1997 \\
\hline Korea & $1997^{*}$ & Korea & 1998 \\
\hline Mexico & $19825 /$ & Mexico & 1988 \\
\hline Mexico & 1994 * & Mexico & 1995 \\
\hline Moldova & 1998 & --- & $\begin{array}{l}-- \\
-\end{array}$ \\
\hline Moldova & 2002 & --- & --- \\
\hline Morocco & $19835 /$ & --- & --- \\
\hline Morocco & $19865 /$ & --- & --- \\
\hline Morocco & $19905 /$ & Morocco & 1996 \\
\hline Pakistan & 1998 & --- & $\begin{array}{l}-- \\
-\end{array}$ \\
\hline Pakistan & 1999 & Pakistan & 2003 \\
\hline Panama & $19835 /$ & --- & --- \\
\hline Panama & 1987 & Panama & 1997 \\
\hline Peru & $19805 /$ & --- & --- \\
\hline Peru & $19835 /$ & Peru & 2002 \\
\hline Philippines & $19835 /$ & Philippines & 1993 \\
\hline Russia & 1998 & Russia & $20036 /$ \\
\hline Slovenia & $19925 /$ & Slovenia & 1996 \\
\hline South Africa & 1985 5/ & South Africa & 1988 \\
\hline South Africa & $19895 /$ & South Africa & 1991 \\
\hline South Africa & $19935 /$ & South Africa & 1994 \\
\hline Thailand & $1997^{*}$ & Thailand & 2001 \\
\hline Turkey & $19825 /$ & Turkey & 1988 \\
\hline Turkey & 2000 * & Turkey & 2001 \\
\hline Ukraine & 1998 & Ukraine & 2002 \\
\hline Uruguay & $19835 /$ & --- & --- \\
\hline Uruguay & $19875 /$ & Uruguay & 1992 \\
\hline Uruguay & 1990 & Uruguay & 2002 \\
\hline Uruguay & 2003 * & Uruguay & 2003 \\
\hline Venezuela & $19835 /$ & Venezuela & 1988 \\
\hline Venezuela & 1990 5/ & Venezuela & 1991 \\
\hline Venezuela & 1995 & Venezuela & 1996 \\
\hline
\end{tabular}

Sources: S\&P (2003), Manasse et al (2003), Dealogic and Fund staff calculations.

A country is defined as suffering a crisis the year it defaults on a bond or a loan as in Standard \& Poor's definition or in the year it received a non-concessional IMF loan in excess of 100 percent of quota as in Manasse et al. (2003).

21 A country is defined as having gained reaccess the year it issues a sovereign international bond in the capital markets following a crisis episode.

3/ Reaccess episodes are listed following the closest crisis event by calendar date.

4/ Asterisks denote episodes when countries received non-concessional IMF loan in excess of 100 percent of quota and did not restructure debt.

5/ The country defaulted or restructured foreign currency bank loans.

6/ A large public bank issued a global bond. 
Table 2

Summary Statistics $1 /$

\begin{tabular}{|l|r|r|r|r|r|}
\hline \multicolumn{1}{|c|}{ Variable } & Obs. & Mean & Std. Dev. & \multicolumn{1}{c|}{ Min. } & \multicolumn{1}{c|}{ Max. } \\
\hline $\mathrm{i}_{\mathrm{W}}$ & 624 & 7.16 & 3.76 & 1.01 & 16.87 \\
\hline $\mathrm{CA}$ (in percent of GDP) & 648 & -0.01 & 0.06 & -0.17 & 0.52 \\
\hline Debt (in percent of GDP) & 528 & 57.23 & 31.68 & 0.60 & 223.86 \\
\hline$\pi$ & 512 & 107.02 & 502.15 & -1.17 & 7481.66 \\
\hline$\Delta \mathrm{Y}$ & 648 & 2.59 & 5.32 & -34.63 & 13.29 \\
\hline Fiscal primary (in percent of GDP) & 413 & 0.74 & 4.73 & -22.98 & 17.79 \\
\hline Budget balance (in percent of GDP) & 648 & -0.03 & 0.04 & -0.24 & 0.06 \\
\hline Reserves to s.t. debt & 535 & 2.23 & 6.03 & 0.04 & 91.50 \\
\hline Debt service to reserves & 536 & 107.59 & 108.15 & 2.47 & 882.32 \\
\hline Reserves in months of imp & 568 & 3.16 & 2.34 & 0.12 & 12.92 \\
\hline
\end{tabular}

1/ Variable definitions: i w: world interest rates (U.S. T-bill rates); CA: current account balance; Debt: total public debt stock; $\pi$ : inflation rates; $\Delta Y$ :GDP growth rates; Debt: total debt as a share to GDP; CA: current account reserves to s.t. debt: ratio international reserves in U.S. dollars to short-term debt. Debt service to reserves: ratio of total debt service to reserves; Reserves in months of imp: international reserves in months of imports. 
Table 3

Estimation Methodology: Multivariate Probit. Dependent Variable: Reaccess After a Financial Crisis 1/

\begin{tabular}{|c|c|c|c|c|c|c|c|c|c|c|c|}
\hline & & (1) & (2) & (3) & (4) & (5) & (6) & (7) & $(8)$ & (9) & (10) \\
\hline \multirow{2}{*}{ Global Liquidity } & \multirow[b]{2}{*}{$i_{w}$} & \begin{tabular}{|l|}
-0.014 \\
\end{tabular} & -0.01 & -0.011 & -0.012 & -0.009 & -0.015 & \begin{tabular}{|l|l}
-0.016 \\
\end{tabular} & -0.016 & -0.014 & \begin{tabular}{|c|}
-0.011 \\
\end{tabular} \\
\hline & & $(0.003)^{* \star \star}$ & $(0.003)^{* \star \star}$ & $(0.004)^{* \star}$ & $(0.002)^{* \star \star}$ & $(0.005)^{\star}$ & $(0.003)^{* \star *}$ & $(0.003)^{\star \star \star}$ & $(0.003)^{\star \star \star}$ & $(0.003)^{\star \star \star}$ & $(0.003)^{\star \star \star \star}$ \\
\hline \multirow{10}{*}{$\begin{array}{l}\text { Commitment } \\
\text { to repay }\end{array}$} & \multirow{2}{*}{ Debt } & -0.037 & & & & & -0.045 & \begin{tabular}{l|l|}
-0.051 \\
\end{tabular} & -0.055 & -0.032 & -0.046 \\
\hline & & $(0.024)$ & & & & & $(0.027)^{*}$ & $(0.029)^{*}$ & $(0.029)^{*}$ & $(0.024)$ & $(0.026)^{\star}$ \\
\hline & \multirow{2}{*}{$\pi$} & & 0.000 & & & & & & & & \\
\hline & & & $(0.000)^{*}$ & & & & & & & & \\
\hline & \multirow{2}{*}{ Fiscal Primary } & & & 0.001 & & & & & & & \\
\hline & & & & $(0.000)$ & & & & & & & \\
\hline & \multirow{2}{*}{ Budget Balance } & & & & -0.142 & & & & & & \\
\hline & & & & & $(0.180)$ & & & & & & \\
\hline & \multirow{2}{*}{ ICRG } & & & & & 0.002 & & & & & \\
\hline & & & & & & $(0.001)^{* *}$ & & & & & \\
\hline \multirow{12}{*}{ Ability to repay } & \multirow{2}{*}{ CA } & 0.286 & 0.329 & 0.604 & 0.184 & 0.515 & & & & & \\
\hline & & $(0.159)^{\star}$ & $(0.167)^{\star \star}$ & $(0.259)^{\star \star}$ & $(0.101)^{\star}$ & $(0.245)^{\star \star}$ & & & & & \\
\hline & \multirow{2}{*}{ Reserves to imp } & & & & & & 0.002 & & & & \\
\hline & & & & & & & $(0.000)$ & & & & \\
\hline & \multirow{2}{*}{$\begin{array}{l}\text { Reserves to s.t. } \\
\text { debt }\end{array}$} & & & & & & & 0.000 & & & \\
\hline & & & & & & & & $(0.000)$ & & & \\
\hline & \multirow{2}{*}{$\begin{array}{l}\text { Debt service to } \\
\text { Reserves }\end{array}$} & & & & & & & & 0.000 & & \\
\hline & & & & & & & & & $(0.000)$ & & \\
\hline & \multirow{2}{*}{ CA_1 } & & & & & & & & & 0.275 & \\
\hline & & & & & & & & & & $(0.162)^{\star}$ & \\
\hline & \multirow{2}{*}{ IMF Program } & & & & & & & & & & 0.007 \\
\hline & & & & & & & & & & & $(0.004)^{\star}$ \\
\hline \multirow{2}{*}{ Expected return } & \multirow{2}{*}{$\Delta Y_{-} 1$} & 0.002 & 0.002 & 0.002 & 0.002 & -0.001 & 0.001 & 0.002 & 0.002 & 0.002 & 0.002 \\
\hline & & $(0.001)^{*}$ & $(0.000)$ & $(0.000)$ & $(0.000)$ & $(0.003)$ & $(0.000)$ & $(0.000)$ & $(0.001)^{*}$ & $(0.001)^{\star}$ & $(0.001)^{\star}$ \\
\hline \multicolumn{2}{|l|}{ Observations } & 486 & 494 & 383 & 598 & 448 & 475 & 458 & 459 & 486 & 377 \\
\hline \multicolumn{2}{|l|}{ Wald } & 25.43 & 20.59 & 11.62 & 27.14 & 19.07 & 25.68 & 26.42 & 26.29 & 29.18 & 19.87 \\
\hline \multirow{2}{*}{\multicolumn{2}{|c|}{ LogL }} & -99.54 & -102.91 & -101.24 & -124.46 & -111.86 & -99.78 & -96.28 & -96.25 & -99.62 & -65.63 \\
\hline & & 0.14 & 0.09 & 0.06 & 0.09 & 0.07 & 0.13 & 0.13 & 0.13 & 0.14 & 0.13 \\
\hline
\end{tabular}

- Robust standard errors in parenthe

1/ Variable definitions: i w: world interest rates (US rates); $\triangle \mathrm{Y}$ :GDP growth rates; Debt: total debt to GDP; CA: current account balances; Reserves to imp: reserves in

$\overrightarrow{0}$ months of imports; Debt service to reserves: ratio of total debt service to reserves; Reserves to s.t. debt: ratio reserves in U.S. dollars to short term debt; icrg:country risk 
N Table 4

Estimation Methodology: Probit with Instrumental Variables

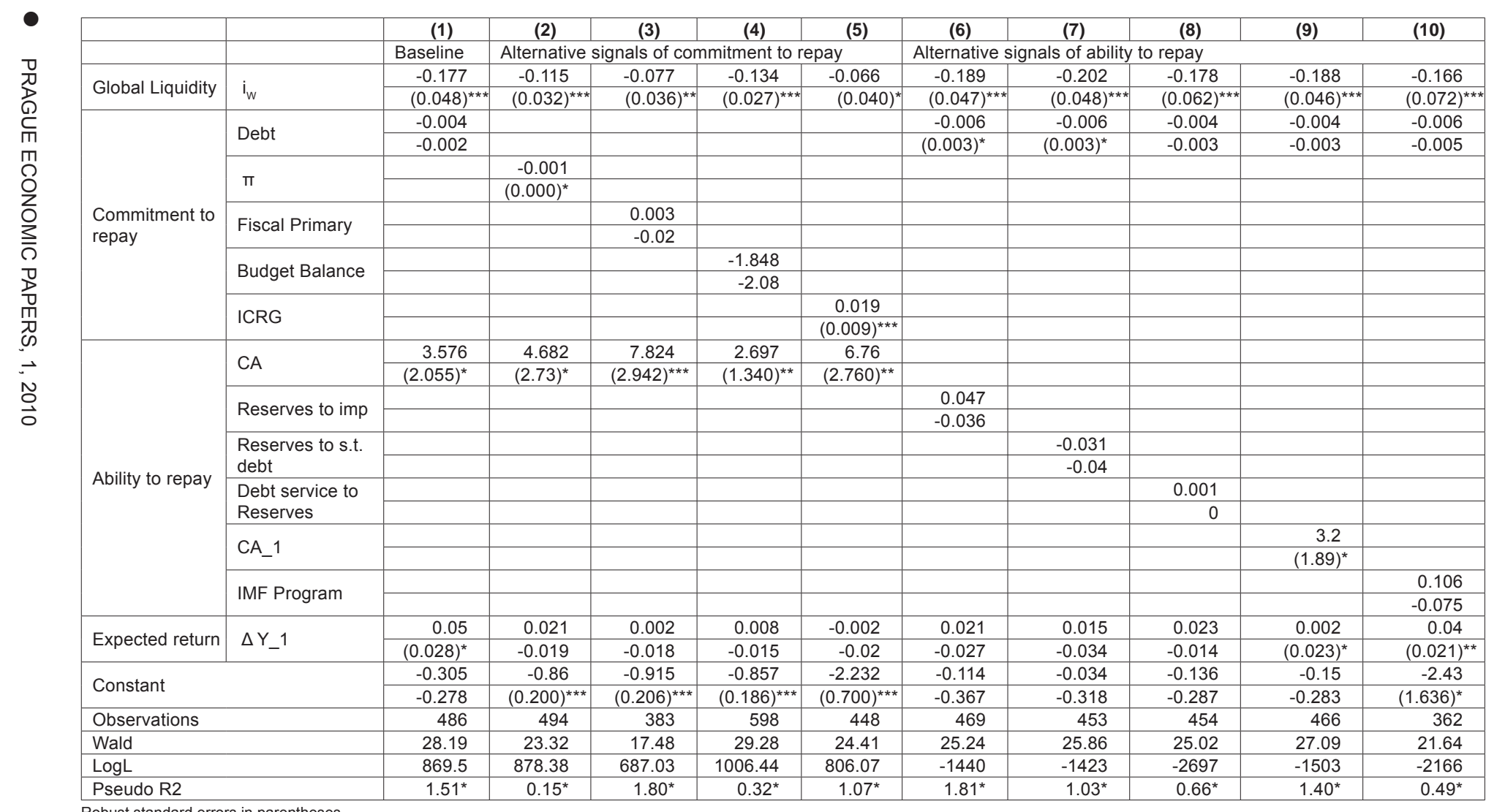

Robust standard errors in parentheses

*significant at 10\%; ** significant at 5\%; *** significant at 1\%. 1/Variable definitions: i w: world interest rates (U.S. rates); $\triangle Y$ : GDP growth rates; Debt: total debt to GDP; CA: current account balances; Reserves to imp: reserves in months of imports; Debt service to reserves: ratio of total debt service to reserves; Reserves to s.t. debt: ratio reserves in U.S. dollars to short term debt; icrg: country risk indicator; iMF program: log size approved IMF program. 